\title{
Medical management of variceal bleeding in patients with cirrhosis
}

\author{
Juan G Abraldes MD, Alessandra Dell'Era MD, Jaime Bosch MD
}

\begin{abstract}
JG Abraldes, A Dell'Era, J Bosch. Medical management of variceal bleeding in patients with cirrhosis. Can J Gastroenterol 2004;18(2):109-113.
\end{abstract}

Bleeding from gastroesophageal varices is a frequent and often deadly complication of cirrhosis. The key factor in the natural history of esophageal varices is increased portal pressure, which in cirrhosis is due to the combination of increased hepatic vascular resistance and increased portal collateral blood flow. The maintenance and aggravation of this situation leads to the progressive dilation of the varices and thinning of the variceal wall, until the tension exerted by the variceal wall exceeds the elastic limit of the vessel, leading to variceal hemorrhage. Mortality from a variceal bleeding episode has decreased in the last two decades from $40 \%$ to $20 \%$ due to the implementation of effective treatments and improvement in the general medical care. Initial treatment should include adequate fluid resuscitation and transfusion to maintain the hematocrit at $25 \%$ to $30 \%$, and prophylactic antibiotics (norfloxacin or amoxicillin-clavulanic acid). It is currently recommended that a vasoactive drug be started at the time of admission. Drug therapy may be started during transferal to hospital by medical or paramedical personnel and maintained for up to five days to prevent early rebleeding. Terlipressin, a vasopressin derivative, is the preferred agent because of its safety profile and proven efficacy in improving survival. Somatostatin is as effective as terlipressin, but may require higher than the usually recommended dosage. Octreotide is effective in conjunction with endoscopic therapy, but is the second choice because it has not been shown to reduce mortality. Vasopressin may be used where terlipressin is not available, but should be given in combination with transdermal nitroglycerin. Endoscopic elastic band ligation is the recommended endoscopic treatment, but injection sclerotherapy is still employed in many centres for active variceal bleeding. Failures of medical therapy (drugs plus endoscopic therapy) should undergo a second course of endoscopic therapy before proceeding to transjugular intrahepatic portosystemic shunt or, in rare occasions, to portosystemic shunt surgery. Administration of recombinant activated factor VII may decrease the number of treatment failures among patients with advanced liver failure (Child-Pugh class B and C).

Key Words: Medical therapy; Variceal bleeding; Vasoactive drugs

\section{Traitement médical des saignements variqueux chez les patients cirrhotiques}

Les saignements variqueux gastro-oesophagiens constituent une complication fréquente, et souvent mortelle, de la cirrhose. Le principal facteur de l'évolution naturelle des varices oesophagiennes est l'augmentation de la pression portale, qui, dans les cas de cirrhose, est due à l'augmentation de la résistance vasculaire hépatique et à l'augmentation de la circulation sanguine collatérale dans le système porte. Le maintien et l'aggravation de cette dynamique aboutissent à la dilatation progressive des varices et à l'amincissement de leurs parois jusqu'à ce que la tension exercée par les parois dépasse la limite d'élasticité des vaisseaux touchés et les fasse éclater, entraînant une hémorragie variqueuse. La mortalité attribuable à ces épisodes hémorragiques a diminué au cours des vingt dernières années; elle est passée de 40 à 20 \% grâce à l'arrivée de nouveaux traitements et à l'amélioration des soins médicaux généraux. Le traitement initial devrait prévoir un remplissage vasculaire adéquat et des transfusions, pour maintenir le taux d'hématocrite entre 25 et $30 \%$, ainsi que l'administration prophylactique d'antibiotiques (norfloxacine ou amoxilline-acide clavulanique). Il est également recommandé d'amorcer un traitement vasomoteur au moment de l'admission. Le traitement peut commencer durant le transport à l'hôpital, par du personnel médical ou paramédical et se poursuivre pendant cinq jours pour prévenir les rechutes. La terlipressine, un dérivé de la vasopressine, est le médicament à privilégier en raison de sa marge d'innocuité et de son efficacité avérée pour améliorer la survie. La somatostatine est aussi efficace que la terlipressine, mais elle peut nécessiter une posologie plus élevée que celle qui est généralement recommandée. L'octréotide, de son côté, se montre efficace en association avec le traitement endoscopique, mais il s'agit d'un médicament de deuxième intention parce qu'il n'a pas prouvé son efficacité à réduire la mortalité. Enfin, la vasopressine peut remplacer la terlipressine si cette dernière n'est pas disponible, mais elle devrait être administrée en association avec de la nitroglycérine transdermique. Il est recommandé de procéder à la ligature élastique par endoscopie, mais les injections sclérosantes sont aussi pratiquées dans de nombreux centres pour les hémorragies variqueuses en évolution. En cas d'échec du traitement médical (médicaments et traitement endoscopique), il faudrait procéder à une seconde tentative de traitement endoscopique avant d'effectuer une anastomose porto-systémique intrahépatique par voie transjugulaire ou, en de rares occasions, une anastomose porto-systémique chirurgicale. Enfin, l'administration de facteur VII activé recombinant peut diminuer le nombre d'échecs de traitement dans les cas d'insuffisance hépatique évoluée (classes B et $\mathrm{C}$ selon Child-Pugh).

\section{EPIDEMIOLOGY AND NATURAL HISTORY}

Massive gastrointestinal bleeding is one of the most frequent and severe complications of cirrhosis. Approximately $80 \%$ of bleeding episodes are due to ruptured gastroesophageal varices (1). Variceal bleeding is often very severe. In fact, approximately $5 \%$ to $8 \%$ of patients die within $48 \mathrm{~h}$ from uncontrolled bleeding $(2,3)$. Active bleeding at endoscopy (4), bacterial infection (5) and hepatic venous pressure

Presented at the $16^{\text {th }}$ International Course on Therapeutic Endoscopy, Toronto, Ontario, October 2003

Hepatic Hemodynamic Laboratory, Liver unit, IMD, Hospital Clinic, Institut d'Investigacions Biomèdiques August Pi i Sunyer (IDIBAPS), University of Barcelona, Spain

Correspondence: Dr J Bosch, Liver Unit, Hospital Clínic, C. Villarroel 170, 08036 Barcelona, Spain. Telephone +0034-93-227-54-10, fax+0034-93-227-98-56, e-mail jbosch@clinic.ub.es 


\section{Increased Portal Pressure}

\section{$\downarrow$}

Increased Variceal Size

$$
\downarrow
$$

\section{Increased Variceal Wall Tension}

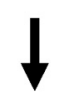

\section{Variceal Rupture}

Figure 1) Mechanism for variceal rupture

gradient (HVPG) greater than $20 \mathrm{mmHg}$ early after admission (6) are poor prognostic factors.

The incidence of rebleeding within the first six weeks ranges from $30 \%$ to $40 \%$ (3). Almost one-half of all rebleeding episodes occur within the first five days (7), and such episodes are associated with a poor prognosis. Predictive factors include bleeding from gastric varices, active bleeding at emergency endoscopy, low serum albumin, renal failure and HVPG greater than $20 \mathrm{mmHg}(3)$.

Mortality rates at six weeks have decreased from 30\% to $50 \%$ in the 1970 s to approximately $20 \%$ now $(8,9)$. Mortality is associated with the presence of severe liver disease (as reflected by the Child-Pugh score), hepatocellular carcinoma or renal failure, or if bleeding cannot be controlled (10).

\section{PATHOPHYSIOLOGY OF VARICEAL BLEEDING}

Variceal bleeding is the culmination of a sequence of events that include increased portal vein pressure. Once varices develop, progressive dilation leads to increases in wall tension, until they finally rupture. Erosion of the esophageal wall, due to esophagitis or deglutory trauma, is not thought to contribute to major bleeding.

The pressure gradient in any vascular system depends on the relationship between the flow within the system and the resistance opposing that flow. According to Ohm's law, the portal pressure gradient $(\mathrm{PPG})$ can be defined as:

$$
\mathrm{PPG}=\text { portocollateral blood flow } \times \text { resistance }
$$

Elevated portal pressure is, therefore, caused by increases in either blood flow or vascular resistance. Many studies have shown that the initial factor leading to portal hypertension in cirrhosis is an increase in hepatic resistance $(11,12)$. Whenever portal pressure rises above normal values, collateral circulation begins to develop so as to decompress the portal system; gastroesophageal varices are the most prevalent and clinically relevant of these collaterals. Collateralization of the portal system is accompanied by splanchnic vasodilation, which increases portal venous inflow and, in turn, exacerbation of portal hypertension (12).
The portal pressure gradient is most commonly evaluated clinically by measurement of its equivalent, the HVPG. A threshold value of 10 to $12 \mathrm{mmHg}$ is necessary for development of esophageal varices, and is known as "clinically significant portal hypertension" $(13,14)$. Therefore, variceal bleeding does not occur if the HVPG does not reach $12 \mathrm{mmHg}$ or if it falls below that level $(15,16)$.

The 'explosion theory' is widely accepted as the explanation for variceal rupture (17). According to this hypothesis, the key factor is increased hydrostatic pressure inside the varix, with ensuing increases in variceal size and decreases in wall thickness (Figure 1). Hemorrhage occurs when the tension exerted by the thin wall exceeds a critical value determined by the elastic limit of the vessel. Frank's modification of Laplace's law states that variceal wall tension is directly proportional to the transmural variceal pressure (the difference between intravariceal and esophageal luminal pressure) and the radius of the varix, and inversely proportional to the thickness of the variceal wall. This concept is supported by clinical observations that increased variceal pressure, increased variceal size and the presence of red colour signs (which indicate reduced wall thickness) are independent predictors of the risk of variceal bleeding (3). A recent study found that an admission HVPG of greater than $20 \mathrm{mmHg}$ (which occurs in $40 \%$ of the total population) was correlated with uncontrolled bleeding, early rebleeding, one-year mortality, transfusion requirements, time spent in the intensive care unit and duration of hospitalization (6).

\section{GENERAL MANAGEMENT}

Variceal bleeding is a medical emergency and its management should be undertaken in an intensive care setting by a team of experienced medical staff, including well-trained nurses, clinical hepatologists, endoscopists, interventional radiologists and surgeons. Lack of these facilities warrants immediate referral to an appropriate institution. Decision-making should follow written guidelines developed to optimize the resources of each centre.

Initial therapy is aimed at correcting hypovolemia, achieving hemostasis and preventing complications (such as renal failure, infection and hepatic decompensation) that increase the risk of rebleeding and death $(1,3,18)$. In the past, specific therapy was usually given after initial resuscitation and diagnostic endoscopy. Nowadays, however, pharmacotherapy can be initiated early in the course of treatment, even during transfer to the hospital.

Blood volume replacement should commence as quickly as possible, but overtransfusion should be avoided because it might cause an increase in portal pressure and lead to further variceal bleeding (19). The goal is to maintain the hematocrit between $25 \%$ and $30 \%$.

Early administration of antibiotics has been shown to improve survival (20), and either norfloxacin by mouth or parenteral amoxicillin-clavulanic acid should be administered at the time of admission (21).

Bronchial aspiration of gastric contents and blood is particularly likely in patients with encephalopathy and during endoscopy. Endotracheal intubation is mandatory if there is any concern about airway safety.

Only recently have clinical studies addressed the role of coagulopathy in the outcome of acute variceal bleeding or possible benefits from its correction. Recombinant activated 
factor VII (Novoseven, NovoNordisk, Denmark) corrects prothrombin time in patients with cirrhosis $(22,23)$. Preliminary data suggest that it significantly improves the results of conventional therapy for patients with Child-Pugh class B or C liver disease, without increasing the incidence of adverse effects (24). This agent may also be useful for uncontrolled bleeding or very early rebleeding.

Hemostatic treatments for variceal bleeding include vasoactive drugs (to decrease portal pressure), endoscopic procedures and portosystemic shunts, either surgical or transjugular intrahepatic portosystemic shunts (TIPS) $(10,25,26)$.

\section{PHARMACOTHERAPY}

The selection of a drug depends on local resources. If available, terlipressin is the first choice, because it is the only agent that has been shown to be superior to placebo in reducing mortality in a randomized double-blind trial (27). Somatostatin or octreotide are second-line agents $(10,28)$. In the absence of these medications, vasopressin plus nitroglycerine is an acceptable option (10).

\section{Vasopressin}

Vasopressin was the first drug used for the treatment of portal hypertension, but was abandoned 25 years ago because of severe cardiovascular toxicity. When vasopressin infusion $(0.4 \mathrm{U} / \mathrm{min}$ for $48 \mathrm{~h})$ is combined with transdermal nitroglycerine $(20 \mathrm{mg} / 24 \mathrm{~h})$, however, the fall in portal pressure is enhanced and there are less marked systemic effects. This combination is safer and more effective than vasopressin alone (10).

\section{Terlipressin}

Terlipressin is a long-acting triglycyl lysine derivative of vasopressin. It has its own vasoactive effects, and also is slowly transformed to vasopressin through cleavage of the triglycyl residues by tissue peptidases (29). It produces less frequent and severe adverse effects than vasopressin (even when the latter is given with nitroglycerine), perhaps because it yields high tissue concentrations and low circulating levels (29). Terlipressin can be administered as soon as variceal bleeding is suspected. The dosage is $2 \mathrm{mg} / 4 \mathrm{~h}$ for the first $48 \mathrm{~h}$, then $1 \mathrm{mg} / 4 \mathrm{~h}$ for up to five days to prevent rebleeding (30). Terlipressin is the only agent that has been shown to improve control of bleeding and survival in randomized controlled trials (RCTs) and metaanalysis $(10,31)$. The overall efficacy in controlling variceal bleeding is $75 \%$ to $80 \%$ at $48 \mathrm{~h}$ and $67 \%$ at five days (30). It is as effective as vasopressin plus nitroglycerine, somatostatin infusion or endoscopic therapy, and is safer than vasopressin plus nitroglycerine $(10,30,31)$.

\section{Somatostatin}

Somatostatin has been used for over two decades (32), based on its ability to decrease portal pressure and collateral blood flow (33). It is usually given as a bolus of $250 \mathrm{mg}$, followed by an infusion of $250 \mathrm{mg} / \mathrm{h}$ that is maintained until bleeding has ceased for $24 \mathrm{~h}$. Treatment can be continued for up to five days to prevent rebleeding (34). It has recently been demonstrated that higher dosages $(500 \mathrm{mg} / \mathrm{h})$ can produce greater clinical efficacy in patients with severe hemorrhage and in those with active bleeding at the time of initial endoscopy (35). Its superiority over placebo or nonactive treatment has been proven in

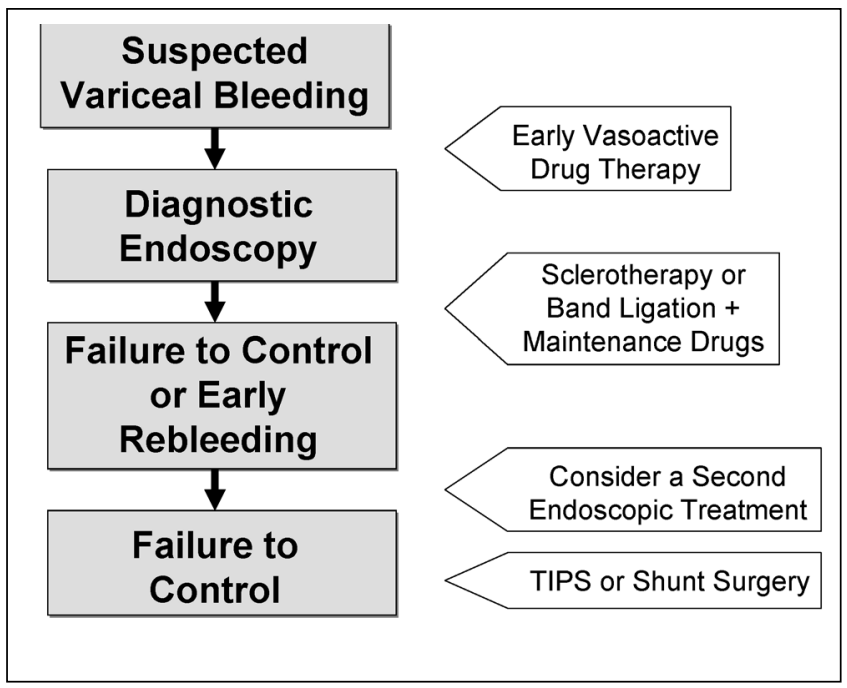

Figure 2) Proposed approach to the management of variceal bleeding. Initial drug therapy: First choice - terlipressin; Second choice - somatostatin or octreotide. TIPS Transjugular intrahepatic portosystemic shunt

RCTs, but mortality is not reduced $(10,28)$. Somatostatin is similar to terlipressin in terms of failure to control bleeding, rebleeding, mortality and adverse effect profile (10). Major toxicity is negligible with this agent.

\section{Octreotide}

Octreotide is a somatostatin analogue that prevents the postprandial increase in portal pressure (28). Despite its longer half-life, it does not exhibit more prolonged hemodynamic effects (36). The optimal dosage schedule has not been determined, although it is usually given as an initial bolus of $50 \mathrm{mg}$, followed by an infusion of 25 or $50 \mathrm{mg} / \mathrm{h}$ (28). As with somatostatin, therapy can be maintained for five days to prevent rebleeding. Its efficacy as a single agent for variceal bleeding is controversial. No benefit was demonstrated in the only placebocontrolled trial of octreotide as initial therapy (37), which might have been due to the rapid development of tachyphylaxis (36). When used with sclerotherapy, however, octreotide has been shown to reduce early rebleeding but not mortality $(10,38)$. Octreotide has been found in RCTs to be superior to vasopressin and equivalent to terlipressin (10). Adverse effects appeared to be less frequent or severe with octreotide than with either vasopressin or terlipressin, but the differences were statistically significant only for vasopressin (10).

\section{COMBINED MEDICAL THERAPY}

The currently recommended treatment for acute variceal bleeding (Figure 2) is to start a vasoactive drug at the time of admission and to undertake therapeutic endoscopy $(39,40)$. Drug therapy can be initiated by medical or paramedical personnel while the patient is being transported to the hospital (27), and can be maintained for up to five days (39). Data from several RCTs support this approach, which achieves initial control of bleeding in approximately $75 \%$ of cases $(27,41,42)$. Pharmacotherapy also enhances the results of either sclerotherapy or band ligation therapy if commenced immediately 
after the procedure $(10,28,38)$. Moreover, endoscopic therapy plus vasoactive therapy is superior to the latter alone (43) (Table 1). However, combination therapy failed to improve six-week mortality compared with endoscopic (44) or drug therapy (43) alone. On the other hand, vasoactive therapy alone is as effective as endoscopic therapy, with significantly less toxicity (45), which raises doubts about the use of endoscopic therapy alone.

\section{MANAGEMENT OF TREATMENT FAILURES}

A single endoscopic retreatment is appropriate for early recurrent bleeding if the bleeding is relatively mild and the patient is stable. Otherwise, the patient should be sent for definitive therapy. In cases of massive bleeding, balloon tamponade may be used as a 'bridge' until definitive therapy can be instituted (46).

Both TIPS and surgical shunts are extremely effective in cases of variceal bleeding, with control rates approaching 95\%. Because patients who require these modalities are generally in poor medical condition, mortality rates remain high

\section{REFERENCES}

1. Cardenas A, Gines P, Uriz J, et al. Renal failure after upper gastrointestinal bleeding in cirrhosis: Incidence, clinical course, predictive factors, and short-term prognosis. Hepatology 2001;34:671-6.

2. D'Amico G, Luca A. Natural history. Clinical-haemodynamic correlations. Prediction of the risk of bleeding. Baillieres Clin Gastroenterol 1997;11:243-56.

3. De Franchis R, Primignani M. Natural history of portal hypertension in patients with cirrhosis. Clin Liver Dis 2001;5:645-63.

4. Ben-Ari Z, Cardin F, McCormick AP, Wannamethee G, Burroughs AK. A predictive model for failure to control bleeding during acute variceal haemorrhage. J Hepatol 1999;31:443-50.

5. Goulis J, Armonis A, Patch D, Sabin C, Greenslade L, Burroughs AK. Bacterial infection is independently associated with failure to control bleeding in cirrhotic patients with gastrointestinal hemorrhage. Hepatology 1998;27:1207-12.

6. Moitinho E, Escorsell A, Bandi JC, et al. Prognostic value of early measurements of portal pressure in acute variceal bleeding. Gastroenterology 1999;117:626-31.

7. Graham DY, Smith JL. The course of patients after variceal hemorrhage. Gastroenterology 1981;80:800-9.

8. D'Amico G, De Franchis R. Cooperative Study Group. Upper digestive bleeding in cirrhosis. Post-therapeutic outcome and prognostic indicators. Hepatology 2003;38:599-612.

9. McCormick PA, O'Keefe C. Improving prognosis following a first variceal haemorrhage over four decades. Gut 2001;49:682-5.

10. D'Amico G, Pagliaro L, Bosch J. Pharmacological treatment of portal hypertension: An evidence-based approach. Semin Liver Dis 1999; 19:475-505.

11. Wiest R, Groszmann RJ. Nitric oxide and portal hypertension: Its role in the regulation of intrahepatic and splanchnic vascular resistance. Semin Liver Dis 1999;19:411-26.

12. Bosch J, Garcia-Pagan JC. Complications of cirrhosis. I. Portal hypertension. J Hepatol 2000;31(Suppl 1):141-56.

13. Viallet A, Marleau D, Huet M, et al. Hemodynamic evaluation of patients with intrahepatic portal hypertension. Relationship between bleeding varices and the portohepatic gradient. Gastroenterology 1975;69:1297-300.

14. Garcia-Tsao G, Groszmann RJ, Fisher RL, Conn HO, Atterbury CE, Glickman M. Portal pressure, presence of gastroesophageal varices and variceal bleeding. Hepatology 1985;5:419-24.

15. Groszmann RJ, Bosch J, Grace ND, et al. Hemodynamic events in a prospective randomized trial of propranolol versus placebo in the prevention of a first variceal hemorrhage. Gastroenterology 1990;99:1401-7.

16. Feu F, Garcia-Pagan JC, Bosch J, et al. Relation between portal
TABLE 1

Efficacy of treatments for acute variceal bleeding*

\begin{tabular}{lc}
\hline Modality & Five-day efficacy (\%) \\
\hline Drug therapy & $65-75$ \\
Endoscopic therapy & 70 \\
Combined drug and endoscopic therapy & 80 \\
\hline
\end{tabular}

*Data from reference 39

$(26,47,48)$. TIPS is preferable over shunt surgery because it is associated with less operative morbidity and mortality (49). Shunt surgery, particularly an $\mathrm{H}$-graft meso-caval shunt, is an alternative in Child class A patients if an experienced surgeon is available.

ACKNOWLEDGEMENT: This work was supported in part by grants from the Instituto de Salud Carlos III (C02/03 and PI 020739). We acknowledge the expert assistance of Ms María Montaño in the preparation of this manuscript. pressure response to pharmacotherapy and risk of recurrent variceal haemorrhage in patients with cirrhosis. Lancet 1995;346:1056-9.

17. Polio J, Groszmann RJ. Hemodynamic factors involved in the development and rupture of esophageal varices: A pathophysiologic approach to treatment. Semin Liver Dis 1986;6:318-31.

18. Castaneda B, Debernardi-Venon W, Bandi JC, et al. The role of portal pressure in the severity of bleeding in portal hypertensive rats. Hepatology 2000;31:581-6.

19. McCormick PA, Jenkins SA, McIntyre N, Burroughs AK. Why portal hypertensive varices bleed and bleed: A hypothesis. Gut 1995;36:100-3.

20. Bernard B, Grange JD, Khac EN, Amiot X, Opolon P, Poynard T. Antibiotic prophylaxis for the prevention of bacterial infections in cirrhotic patients with gastrointestinal bleeding: A meta-analysis. Hepatology 1999;29:1655-61.

21. Rimola A, Garcia-Tsao G, Navasa M, et al. Diagnosis, treatment and prophylaxis of spontaneous bacterial peritonitis: A consensus document. International Ascites Club. J Hepatol 2000;32:142-53.

22. Bernstein DE, Jeffers L, Erhardtsen E, et al. Recombinant factor VIIa corrects prothrombin time in cirrhotic patients: A preliminary study. Gastroenterology 1997;113:1930-7.

23. Ejlersen E, Melsen T, Ingerslev J, Andreasen RB, Vilstrup H. Recombinant activated factor VII ( $\mathrm{rFVIIa}$ ) acutely normalizes prothrombin time in patients with cirrhosis during bleeding from oesophageal varices. Scand J Gastroenterol 2001;36:1081-5.

24. Thabut D, de Franchis R, Bendtsen F, et al. Efficacy of activated recombinant factor VII (rFVIIa; Novoseven) in cirrhotic patients with upper gastrointestinal bleeding: A randomized placebocontrolled double-blind multicenter trial. J Hepatol 2003;38(Suppl 2):13A. (Abst)

25. De Franchis R, Primignani M. Endoscopic treatments for portal hypertension. Semin Liver Dis 1999;19:439-55.

26. Burroughs AK, Patch D. Transjugular intrahepatic portosystemic shunt. Semin Liver Dis 1999;19:457-73.

27. Levacher S, Letoumelin P, Pateron D, Blaise M, Lapandry C, Pourriat JL. Early administration of terlipressin plus glyceryl trinitrate to control active upper gastrointestinal bleeding in cirrhotic patients. Lancet 1995;346:865-8.

28. Abraldes JG, Bosch J. Somatostatin and analogues in portal hypertension. Hepatology 2002;35:1305-12.

29. Bosch J, Lebrec D, Jenkins SA. Development of analogues: Successes and failures. Scand J Gastroenterol 1998;33(Suppl 226):3-13.

30. Escorsell A, Ruiz del Arbol L, Planas R, et al. Multicenter randomized controlled trial of terlipressin versus sclerotherapy in the treatment of acute variceal bleeding: The TEST study. Hepatology 2000;32:471-6. 
31. Ioannou GN, Doust J, Rockey DC. Systematic review: Terlipressin in acute oesophageal variceal haemorrhage. Aliment Pharmacol Ther 2003;17:53-64.

32. Tyden G, Sammegard H, Thulin L, Friman L, Efendic S. Treatment of bleeding esophageal varices with somatostatin. N Engl J Med 1978;299:1466-7. (Lett)

33. Bosch J, Kravetz D, Rodes J. Effects of somatostatin on hepatic and systemic hemodynamics in patients with cirrhosis of the liver: Comparison with vasopressin. Gastroenterology 1981;80:518-25.

34. Escorsell A, Bordas JM, del Arbol LR, et al. Randomized controlled trial of sclerotherapy versus somatostatin infusion in the prevention of early rebleeding following acute variceal hemorrhage in patients with cirrhosis. Variceal Bleeding Study Group. J Hepatol 1998;29:779-88.

35. Moitinho E, Planas R, Bañares R, et al. Variceal Bleeding Study Group. Multicenter randomized controlled trial comparing different schedules of somatostatin in the treatment of acute variceal bleeding. J Hepatol 2001;35:712-8.

36. Escorsell A, Bandi JC, Andreu V, et al. Desensitization to the effects of intravenous octreotide in cirrhotic patients with portal hypertension. Gastroenterology 2001;120:161-9.

37. Burroughs AK. International Octreotide Study Group. Doubleblind RCT of 5 day octreotide versus placebo, associated with sclerotherapy for trial failures. Hepatology 1996;24:352A. (Abst)

38. Corley DA, Cello JP, Adkisson W, Ko WF, Kerlikowske K. Octreotide for acute esophageal variceal bleeding: A meta-analysis. Gastroenterology 2001;120:946-54.

39. De Franchis R. Updating consensus in portal hypertension: Report of the Baveno III Consensus Workshop on definitions, methodology and therapeutic strategies in portal hypertension. J Hepatol 2000;33:846-52.
40. Burroughs AK, Patch DW. Management of variceal haemorrhage in cirrhotic patients. Gut 2001;48:738-40. (Lett)

41. Avgerinos A, Nevens F, Raptis S, Fevery J. Early administration of somatostatin and efficacy of sclerotherapy in acute oesophageal variceal bleeds: The European Acute Bleeding Oesophageal Variceal Episodes (ABOVE) randomised trial. Lancet 1997;350:1495-9.

42. Cales P, Masliah C, Bernard B, et al. French Club for the Study of Portal Hypertension. Early administration of vapreotide for variceal bleeding in patients with cirrhosis. French Club for the Study of Portal Hypertension. N Engl J Med 2001;344:23-8.

43. Villanueva C, Ortiz J, Sabat M, et al. Somatostatin alone or combined with emergency sclerotherapy in the treatment of acute esophageal variceal bleeding: A prospective randomized trial. Hepatology 1999;30:384-9.

44. Bañares R, Albillos A, Rincon D, et al. Endoscopic treatment versus endoscopic plus pharmacologic treatment for acute variceal bleeding: A meta-analysis. Hepatology 2002;35:609-15.

45. D’Amico G, Pietrosi G, Tarantino I, Pagliaro L. Emergency sclerotherapy versus vasoactive drugs for variceal bleeding in cirrhosis: A Cochrane meta-analysis. Gastroenterology 2003;124:1277-91.

46. Bosch J, Abraldes JG, Groszmann R. Current management of portal hypertension. J Hepatol 2003;38(Suppl 1):S54-68.

47. D’Amico G, Pagliaro L, Bosch J. The treatment of portal hypertension: A meta-analytic review. Hepatology 1995;22:332-54.

48. Bosch J. Salvage transjugular intrahepatic portosystemic shunt: Is it really life-saving? J Hepatol 2001;35:658-60.

49. Henderson JM. Salvage therapies for refractory variceal hemorrhage. Clin Liver Dis 2001;5:709-25. 


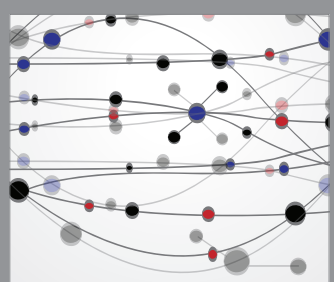

The Scientific World Journal
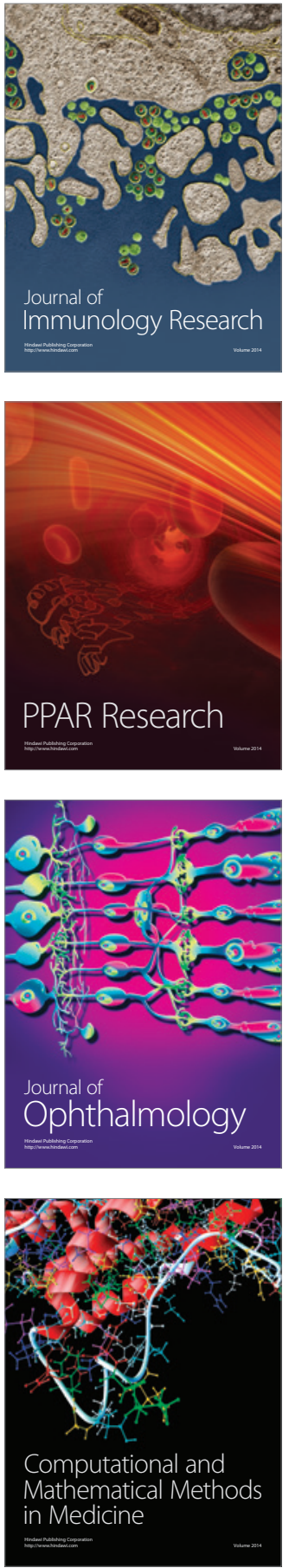

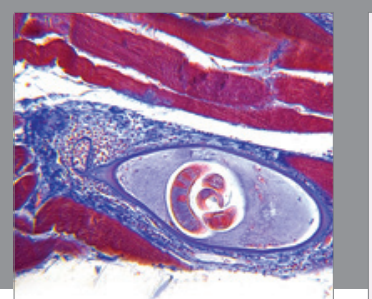

Gastroenterology Research and Practice

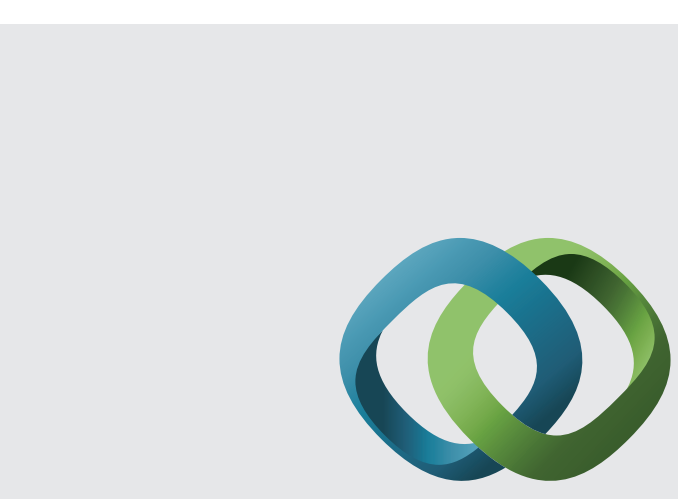

\section{Hindawi}

Submit your manuscripts at

http://www.hindawi.com
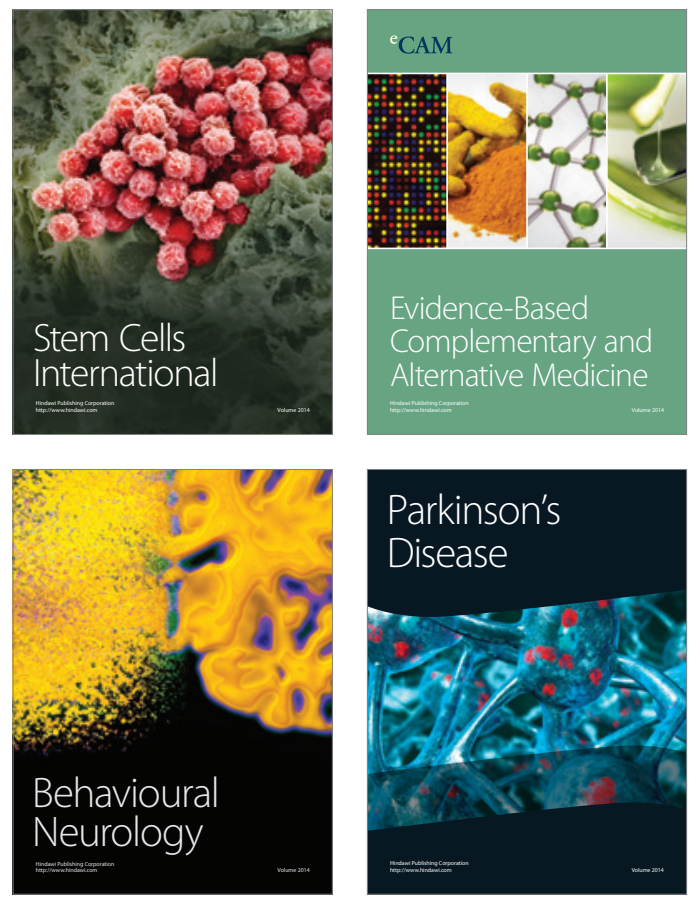
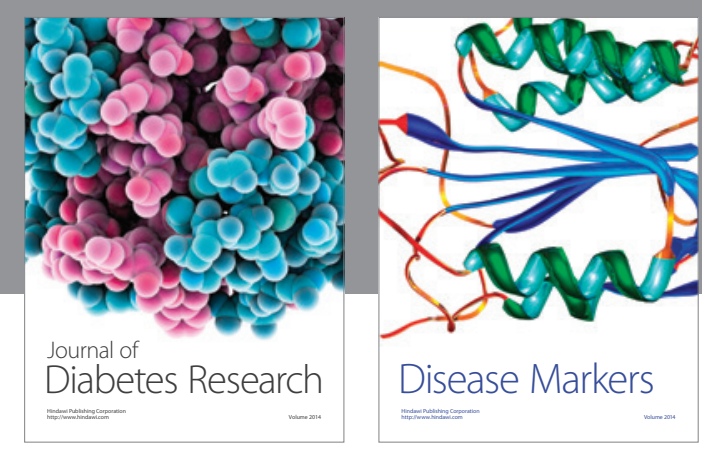

Disease Markers
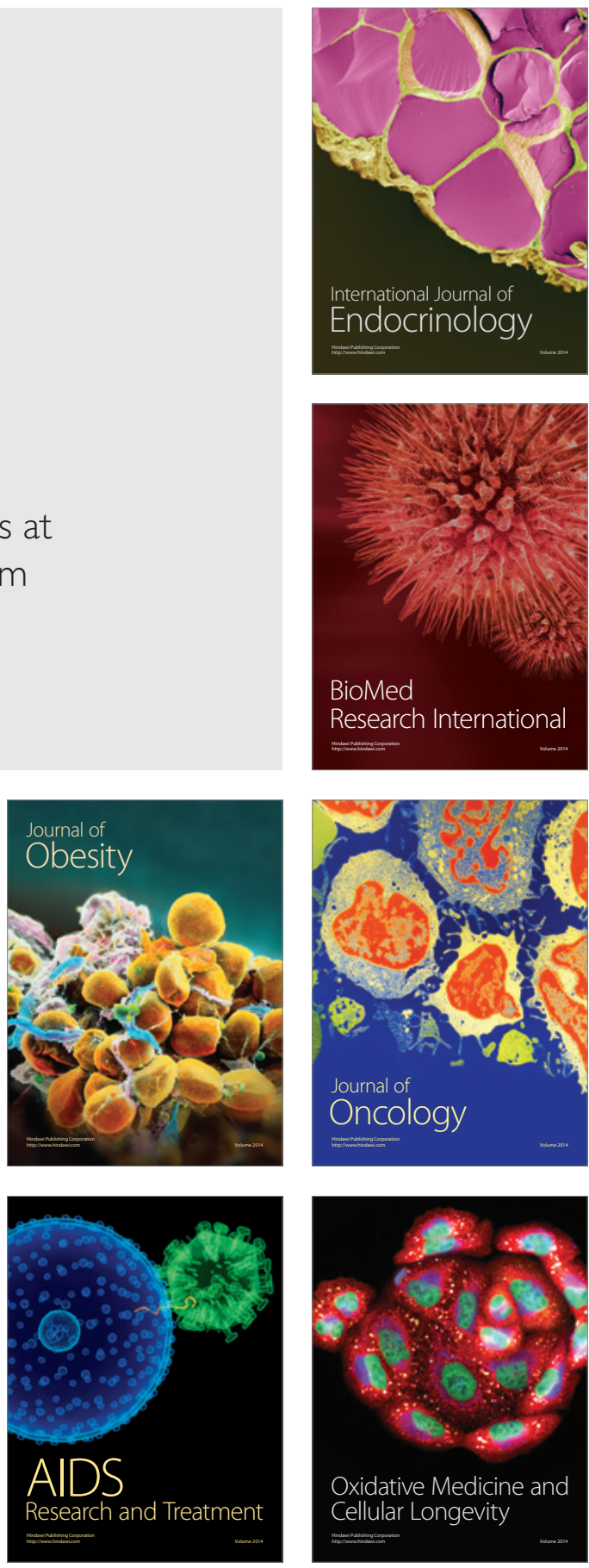